\title{
Urinary Coproporphyrin Isomers I and III in Lead Workers and a Control Group
}

\author{
SHAWKIA MEHANI \\ From the Department of Forensic Medicine, Faculty of Medicine, Ain Shams University, \\ Abbassia, Cairo, U.A.R.
}

The excretory pattern of coproporphyrin I and III isomers has been studied in urine from nine healthy subjects and ro lead-exposed workers with no clinical evidence of lead poisoning.

In normal urine it was found that coproporphyrin I exceeded coproporphyrin III, whereas in lead workers coproporphyrin III predominated, although this was accompanied by an increase in the absolute amount of coproporphyrin $\mathrm{I}$, indicating active haemopoiesis in lead absorption.

Improvements in analytical methods during recent years have made it possible to gain a general picture of the patterns of porphyrin excretion seen in the different porphyria diseases. A clearer view of normal porphyrin metabolism has also been obtained.

It is thought that during the formation of porphyrin III in haemoglobin synthesis, porphyrin $\mathrm{I}$ is also formed by a side reaction. This porphyrin, being of no use for haem formation (Rimington, 1936), is excreted in the urine, bile, and faeces as coproporphyrin $\mathrm{I}$, the amount of which is a good index of erythropoietic activity. Porphyrin III is excreted as coproporphyrin III, but only in excess if there is some toxic action on the blood, as in poisoning with lead, arsenic or sulphonamide drugs. This excretion appears to be due to the blocking of a stage in the production of haemoglobin and not to the destruction of haemoglobin itself.

A review of the literature revealed that very little has been published on the pattern of porphyrin excretion in lead poisoning and none at all on the excretion after lead absorption. In qualitative studies, Watson (1936) and Holeček and Pěničková (1957) reported a greater predominance of isomer III over isomer $\mathrm{I}$ in urine in lead poisoning. A quantitative study by Kench, Lane, and Varley (1952) on urine from seven lead-poisoned workers showed that coproporphyrin I excretion in urine is concomitantly increased with coproporphyrin III, and that the former constituted an average of $30 \%$ of the total coproporphyrin.

Received for publication July 17, 1965.
In normal urine the proportion of the two isomers has been the subject of study by several authors who followed various procedures for the separation of the two isomers. As an example of the variability of figures recorded in the literature, Watson, Hawkinson, Schwartz, and Sutherland (1949) found by a fluorescence quenching technique at least $60 \%$ of the total to be coproporphyrin I, while Comfort, Moore, and Weatherall (1954), using the ChuGreen paper chromatographic method (I95I), obtained a preponderance of coproporphyrin III and Holeček and Pěničková (1957) obtained equal amounts. The most widely accepted view is that the coproporphyrin I isomer predominates.

The present study examines by a paper chromatography technique the excretory pattern of these two metabolites in urine from recently exposed lead workers and a control group.

Ten lead workers have been studied. They had been exposed to lead for periods varying from two to six months with an average of three months. None of them showed clinical evidence of lead poisoning. For comparison, nine spot urine samples from healthy non-exposed subjects have been collected and analysed for coproporphyrin I and III isomers.

\section{Methods}

Haemoglobin Haemoglobin was determined by the oxyhaemoglobin method (Britton, I963) using a Hilger electrophotometer, model H. $810.30 \mathrm{r}$ at $550 \mathrm{~m} \mu$. The results were obtained from standard curves and tables ( $100 \%=\mathrm{Hb} 14.8 \mathrm{~g} . / 100 \mathrm{ml}$.). 
Punctate Basophilic Cells These were counted under dark-ground illumination (Lane, 1949).

Urinary Lead Urinary lead was determined by a modified dithizone method (Dick, Ellis, and Steel, I96I).

$\delta$-Amino-laevulinic Acid in Urine. This was determined by the method of Mauzerall and Granick (1956).

Separation and Determination of Coproporphyrins I and III The method of Chu, Green, and Chu (195I) was the basis of the following procedure. For lead workers, $20 \mathrm{ml}$. of urine, and for normal subjects, Ioo ml., were taken, and the total coproporphyrin (I and III) was determined by the Rimington and Sveinsson method (I950). (For normal subjects it is best to extract about $100 \mathrm{ml}$. of urine before proceeding with the isomer analysis, even though the latter can be accomplished with as little as $2 \mu \mathrm{g}$. of the total porphyrin, since considerable loss of porphyrin may occur during the subsequent purification procedure.) Sodium acetate in $0.5 \mathrm{~g}$. portions was added to the hydrochloric acid extract of total coproporphyrin in a separating funnel and shaken until dissolved. This was repeated until the $p \mathrm{H}$ of the solutions was neutral to bromophenol blue, used as an external indicator. An equal volume of ether was added to the separating funnel and shaken for one minute. The acid layer was run off. The ether was transferred to a $100 \mathrm{ml}$. beaker and taken to dryness under reduced pressure. Methanolic hydrochloric acid ( $10 \%$ conc. $\mathrm{HCl}$ in methyl alcohol), $5 \mathrm{ml}$., was added and allowed to stand overnight. The solution was transferred to a separating funnel with water washes and made up to about $50 \mathrm{ml}$. with water. The porphyrins were extracted with $5 \mathrm{ml}$. portions of chloroform. The chloroform extracts were shaken twice with water, once with $0.1 M$ sodium carbonate, and finally twice with water. The concentration of the porphyrins was ad- justed in the chloroform by comparing the fluorescence of standard solutions of porphyrins.

Three drops of the chloroform solution were chromatographed on Whatman No. I paper with propanol/light petroleum (Analar grade, $\mathrm{I} / 5, \mathrm{v} / \mathrm{v}$ ) for 45 to 60 minutes. The papers were viewed under ultraviolet light to find the porphyrins, and the spots were cut out, and the porphyrins were extracted with chloroform/acetic acid $(5 / \mathrm{I}, \mathrm{v} / \mathrm{v})$, and estimated in the electrophotometer (Unicam SP500) at $406 \mathrm{~m} \mu$.

If the urine contained $z \mu \mathrm{g}$./1. of total coproporphyrin it contained: $x z /(x+y) \mu \mathrm{g}$. coproporphyrin I/l. and $y z /(x+y) \mu \mathrm{g}$. coproporphyrin III/1., where $x$ and $y$ were the optical densities of the chloroform solutions of coproporphyrins I and III respectively.

\section{Results}

The results of analyses for lead, total coproporphyrin, and $\delta$-amino-laevulinic acid in urine, haemoglobin, and basophilic stippled cells in blood in the lead workers indicated a considerable degree of lead absorption compared with similar analyses from 25 control subjects (Mehani, 1965) (Table I). The highest values for urinary lead (219 $\mu \mathrm{g}$./1.), total coproporphyrin in urine $(2,625 \mu \mathrm{g} . / 1$.), and basophilic stippled cells in blood ( $12,000 / \mathrm{million}$ red blood cells), and a relatively low haemoglobin value (12.87 g. $/ 100 \mathrm{ml}$. of blood) were found in worker no. 6 who had worked in the lead industry for four months following a period of eight years in a shipbuilding yard. It is not known whether his previous job had exposed him to lead.

In Table II the percentages of coproporphyrins I and III for control no. 4 have been omitted in calculating the means, as they are more than

TABLE I

Lead and $\delta$-Amino-laevulinic Acid in Urine, and Haemoglobin and Basophilic Stippled Cells IN BLOOD FROM LEAD WORKERS AND A CONTROL GROUP

\begin{tabular}{|c|c|c|c|c|c|}
\hline \multirow{2}{*}{$\begin{array}{l}\text { Worker } \\
\text { No. }\end{array}$} & \multirow{2}{*}{$\begin{array}{l}\text { Exposure } \\
\text { (mths.) }\end{array}$} & \multicolumn{2}{|l|}{ Urine } & \multirow{2}{*}{$\begin{array}{l}\text { Haemoglobin } \\
(\mathrm{g} . / 100 \mathrm{ml} .)\end{array}$} & \multirow{2}{*}{$\begin{array}{l}\text { Punctate Basophils } \\
\text { (per million R.B.C.) }\end{array}$} \\
\hline & & $\begin{array}{l}\text { Lead } \\
(\mu g . / l .)\end{array}$ & $\begin{array}{l}\delta-A L A \\
(\mu g . / l .)\end{array}$ & & \\
\hline I & 2 & $9 \mathrm{I}$ & 630 & I 4.94 & $4,000 \mathrm{SML}$ \\
\hline 2 & $2 \frac{1}{2}$ & 133 & 66,130 & 14.94 & $5,000 \mathrm{SML}$ \\
\hline 3 & 3 & 178 & 7,340 & 14.50 & - \\
\hline 4 & 2 & 162 & 5,840 & 14.06 & $650 \mathrm{SM}$ \\
\hline 5 & 3 & 58 & 21,020 & 14.50 & None \\
\hline 6 & 4 & 219 & 6,980 & $12 \cdot 87$ & $12,000 \mathrm{SML}$ \\
\hline 7 & 6 & I7I & 5,460 & 16.42 & 1,000 SM \\
\hline 8 & 4 & 69 & 5,980 & I6.98 & None \\
\hline 9 & 3 & 155 & 3,940 & $16 \cdot 98$ & - \\
\hline 10 & 4 & 77 & 5,840 & $12 \cdot 13$ & $550 \mathrm{SM}$ \\
\hline Average & 3 & I3I & 12,916 & $14 \cdot 83$ & 2,900 \\
\hline \multicolumn{2}{|c|}{ Average results of 25 non-exposed men } & 15 & 2,019 & 15.60 & None \\
\hline
\end{tabular}


TABLE II

COPROPORPHYRINS I AND III AND TOTAL URINARY COPROPORPHYRINS FROM IO LEAD WORKERS AND NINE CONTROLS

\begin{tabular}{|c|c|c|c|c|c|}
\hline \multirow{2}{*}{$\begin{array}{l}\text { Lead } \\
\text { Workers }\end{array}$} & \multirow{2}{*}{$\begin{array}{l}\text { Total } \\
\text { Coproporphyrin } \\
\text { ( } \mu g . / l .)\end{array}$} & \multicolumn{2}{|c|}{ Coproporphyrin III } & \multicolumn{2}{|c|}{ Coproporphyrin I } \\
\hline & & $\mu g . / l$. & $\%$ of total & $\mu g . / l$. & $\%$ of total \\
\hline $\mathbf{r}$ & 1,125 & 984 & 87 & I4I & 13 \\
\hline 2 & 740 & 598 & 81 & 142 & 19 \\
\hline 3 & 342 & 230 & 67 & 112 & 33 \\
\hline 4 & 550 & 434 & 79 & 116 & $2 \mathrm{I}$ \\
\hline 5 & 630 & 568 & 90 & 62 & ro \\
\hline 6 & 2,625 & 2,289 & 87 & 336 & 13 \\
\hline 7 & 683 & 484 & 71 & 199 & 29 \\
\hline & 230 & 199 & 87 & 3 I & 13 \\
\hline 9 & 340 & 253 & 74 & 87 & 26 \\
\hline 10 & 416 & 348 & 84 & 68 & 16 \\
\hline Average & 768 & 639 & $8 I$ & 129 & $\begin{array}{l}\text { 19 } \\
\text { S.D. } \pm \\
\text { S.E. } \pm\end{array}$ \\
\hline
\end{tabular}

\begin{tabular}{|c|c|c|c|c|c|}
\hline \multicolumn{6}{|l|}{ Controls } \\
\hline I & $3 I$ & 17 & 55 & 14 & 45 \\
\hline 2 & 23 & 12 & 52 & II & 48 \\
\hline 3 & 43 & 19 & 44 & 24 & 56 \\
\hline 4 & 40 & 29 & $73^{*}$ & II & $27^{*}$ \\
\hline 5 & 45 & 13 & 29 & 32 & 71 \\
\hline 6 & 29 & 12 & $4 I$ & 17 & 59 \\
\hline 7 & 29 & 9 & 31 & 20 & 69 \\
\hline 8 & 54 & 25 & 46 & 29 & 54 \\
\hline 9 & 54 & 17 & 31 & 37 & 69 \\
\hline Average & 39 & 17 & $4 I$ & 22 & $\begin{array}{l}59 \\
\text { S.D. } \pm 10 \% \\
\text { S.E. } \pm 3.5 \%\end{array}$ \\
\hline
\end{tabular}

* These values have been omitted in calculating the means as they are over three standard deviations from them.

3 standard deviations from them. Therefore, in normal human urine coproporphyrin I isomer comprised from 45 to $71 \%$ of the total coproporphyrin with an average of $59 \% \pm 10 \%$ (S.D.) or $59 \% \pm$ $3.5 \%$ (S.E.). These results indicate that ( 1 ) in normals the mean value of coproporphyrin $I$ is significantly $(P<0.05)$ greater than $50 \%$; (2) about one in six normals will give percentages less than $50 \%$ as the S.D. is $10 \%$; this is not inconsistent with the results obtained by workers who find equal amounts of both isomers, but is inconsistent with any suggestion that coproporphyrin III greatly exceeds coproporphyrin $I$ in normals.

In the lead workers, coproporphyrin III predominated with an average of $81 \%$. Even though coproporphyrin I was increased about sixfold it only constituted $19 \% \pm 7.8 \%$ (S.D.) or $19 \% \pm 2.4 \%$ (S.E.) of the total coproporphyrin, which was increased 20-fold (Table II).

\section{Discussion}

In the small groups examined it was found that in normal human urine coproporphyrin I consti- tuted $59 \%$ of the total coproporphyrin. This is in agreement with Hoerburger and Fink (1935), Watson (1936), Grotepass (1938), Watson et al. (1949), Kench et al. (1952), and Lockwood and Bloomfield (1954) who reported that the type I isomer predominates in normal urine. It is not inconsistent with that of Holeček and Pěničková (1957) who found that isomers I and III are formed in equal amounts in the urine of healthy subjects. It does not support the work of Comfort et al. (1954) who reported that isomer III much exceeded isomer $I$ in normal urine. These authors admitted that, while extracting porphyrins from large volumes of normal urine, they failed to eliminate impurities from the material, thus probably causing defective separation of the two isomers.

In lead workers, despite the reversal of the normal isomer ratio, i.e., coproporphyrin III predominated, it was found that the absolute amount of coproporphyrin I regularly increased with increase of coproporphyrin III (Table II, column 5). The predominance of coproporphyrin III in urine from lead workers was in accord with the widespread view that lead exerts a toxic action on the enzymatic 
system at certain stages of haem biosynthesis, resulting in decreased utilization of coproporphyrin III isomer, defective haemoglobinization, and short survival of red blood cells. Thus, to compensate for the threatened anaemia and to supply sufficient coproporphyrin III for the requirements of haemoglobin formation, the whole level of porphyrin synthesis has to be raised, and relatively large quantities of the useless coproporphyrin I are formed and eliminated. Its amount is an index of the degree of haemopoietic activity, which varies with the intensity and duration of lead absorption.

The present finding is in agreement with that of Kench et al. (1952) who have shown that, with the increase of urinary coproporphyrin III in lead poisoning, there is an increase in coproporphyrin I which constitutes an average of $30 \%$ of the total coproporphyrin. But in this study coproporphyrin I constituted only $19 \%$ of the total coproporphyrin. As urine from recently exposed lead workers was examined in the present study, this indicated that the haemopoietic activity was greater in poisoning than absorption.

A similar conclusion has been reached by Sweeney (1963) who, in South Africa, studied the pattern of faecal porphyrin excretion in normal subjects and porphyric patients. Sweeney reported that in normal persons $70 \%$ of the faecal coproporphyrin is of the isomer I series, whereas in porphyric patients 75 to $85 \%$ of the faecal coproporphyrin was isomer III. He also reported that in an acute attack there appears to be a relative increase in coproporphyrin I, which forms up to $50 \%$ of faecal coproporphyrin.
Grateful thanks are due to Professor R. C. Browne for allowing a space for this study in his laboratory, to Professor C. Rimington for his helpful suggestions, to Dr. J. Steel for supervision, to Dr. F. Herbert for supplying standard solutions of coproporphyrins I and III, to Mr. W. Ellis for technical assistance, and to the Ministry of Education of the United Arab Republic who supported this work.

\section{REFERENCES}

Britton, C. J. C. (1963). Disorders of the Blood, gth ed., p. 721. Churchill, London.

Chu, T. C., Green, A.A., and Chu, E. J. (195I). F. biol. Chem., 190, 643 .

Comfort, A., Moore, H., and Weatherall, M. (1954). Biochem. f., 58, 177 .

Dick, J. M., Ellis, R. W., and Steel, J. (196r). Brit. F. industr. Med., 18, 283.

Grotepass, W. (1938). Hoppe-Seylers physiol. Chem., 253, 276.

Hoerburger, W., and Fink, H. (1935). Ibid., 236, 136.

Holeček, V., and Pěničková, M. (1957). Brit.f. industr. Med., I4, 198.

Kench, J. E., Lane, R. E., and Varley, H. (1952). Ibid., 9, I33.

Lane, R. E. (1949). Ibid., 6, 125.

Lockwood, W. H., and Bloomfield, B. (1954). Aust. F. exp. Biol. Med. Sci., 32, 733.

Mauzerall, D., and Granick, S. (1956). F. biol. Chem., 219, 435 .

Mehani, S. (1965). Environmental, Pulmonary and Laboratory Studies on Lead-exposed Workers. A Ph.D. Thesis submitted for discussion in the University of Newcastle upon Tyne, p. 74 .

Rimington, C. (1936). Onderstepoort F. vet. Sci., 7, 567.

—, and Sveinsson, S. L. (1950). Scand. F. clin. Lab. Invest., 2, 209.

Sweeney, G. D. (1963). South African F. Lab. clin. Med., $9,182$.

Watson, C. J. (1936). F. clin. Invest., 15, 327.

- Hawkinson, V., Schwartz, S., and Sutherland, D. (I949). Ibid., 28, 447. 